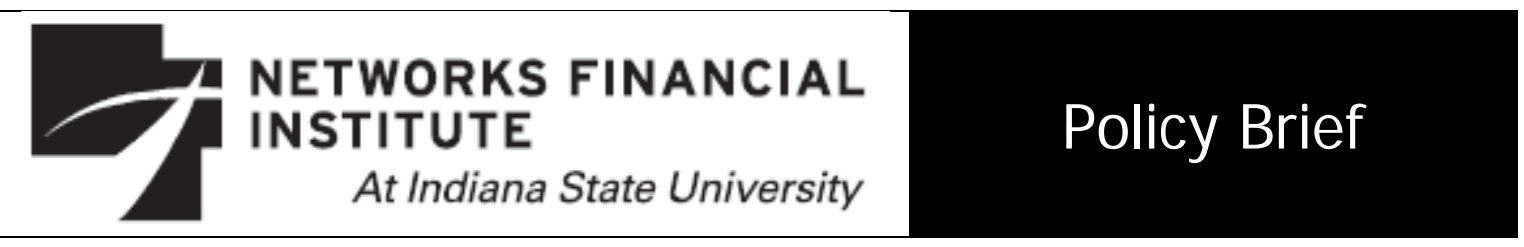

2009-PB-13

December 2009

\title{
Analyzing the Role for a Consumer Financial Protection Agency Sharon Tennyson
}

Albstract: In the debate over the proposed establishment of a new Consumer Financial Protection Agency, much attention has been given to discussion of whether consumers are irrational or incompetent and therefore need paternalistic regulators to look after them, and whether inadequate consumer protection regulation was a contributor to the financial crisis. Arguments over these questions are misplaced. Consumer protection regulation is commonplace in financial markets, and is essential even where consumers are fully rational and financial crises are distant. The potential role for a CFPA should first be examined based on consideration of the benefits and shortcomings of current consumer protection regulation, and how a dedicated consumer protection regulator would be likely to change things. Specific details of proposed legislation that affect the structure and authority of a CFPA should be evaluated separately rather than being used to determine whether such an agency is a good idea or a bad one. Consideration of the general principles for and against establishment of an independent CFPA may help to illuminate the strengths and weaknesses of specific legislative proposals.

Albout the Author: Sharon Tennyson is Associate Professor in the Department of Policy Analysis and Management at Cornell University. Dr. Tennyson is a noted expert on economic and policy issues related to insurance and has published extensively on topics related to government regulation of insurance markets, insurance fraud, insurance distribution and consumer attitudes and knowledge of insurance. Her research has received funding from a variety of sources including the National Science Foundation, and has been published in high quality economics, insurance and finance journals and in prestigious edited collections. Dr. Tennyson is a member of several national organizations and editorial boards, and is a past president of the Risk Theory Society. She holds a Ph.D. in economics from Northwestern University, and was previously on the faculty of the Wharton School of the University of Pennsylvania.

Keywords: banking, regulation, consumer protection, consumer financial protection agency.

\section{J EL Classifications: G28, K23.}

The views expressed are those of the individual author and do not necessarily reflect official positions of Networks Financial Institute. Please address questions regarding content to Sharon Tennyson at sharon.tennyson@cornell.edu. Any errors or omissions are the responsibility of the author. NFI working papers and other publications are available on NFI's website (www. networksfinancialinstitute.org). Click "Thought Leadership" and then "Publications/Papers." 


\section{Analyzing the Role for a Consumer Financial Protection Agency}

\section{Introduction}

Recent financial reform legislation has proposed the creation of a new federal agency charged with protecting consumers from unfair, deceptive and abusive practices by bank and non-bank financial institutions. ${ }^{1}$ The proposed Consumer Financial Protection Agency (CFPA) would be a federal agency with a dedicated funding stream, financed at least in part by fees from regulated entities. The agency would have authority over credit, savings, and payment instruments, and other consumer financial products and services except for investment products and services regulated by the Securities Exchange Commission (SEC) or the Commodities Futures Trading Commission (CFTC). ${ }^{2}$ The CFPA would become the sole federal overseer of consumer protection in financial services, with broad authority to supervise and examine providers of covered financial products, enforce consumer protection regulations, write new rules and take enforcement actions for violations.

Establishment of a CFPA would represent a sharp departure from the current U.S. practice of financial regulatory divisions along institutional boundaries. Currently separate regulatory agencies oversee different sectors of the financial services industry. Consolidating authority for consumer protection regulation within a CFPA would remove the consumer protection functions from these regulators and would also reduce the role of the Federal Trade Commission (FTC) in protecting consumers of financial services. ${ }^{3}$

\footnotetext{
${ }^{1}$ H.R. 3126, The Consumer Financial Protection Agency Act of 200,9 has been passed by the House Financial Services Committee; parts of this bill are included in the comprehensive financial reform bill H.R. 4173 recently passed by the full House. The Restoring American Financial Stability Act of 2009 is under consideration by the Senate Banking Committee.

${ }^{2}$ Insurance, which is regulated by the states, would also be exempt from the CFPA's authority.

${ }^{3}$ The FTC, as the primary federal consumer protection agency, exercises some oversight of deceptive practices of non-bank financial institutions that do not fall under the authority of specific financial regulatory agencies; the FTC is prohibited from regulating banks, securities or insurance companies.
} 
This proposed restructuring has drawn strong praise from some observers and strong criticism from others. In the debate, much attention has been given to discussion of whether consumers are irrational and need paternalistic regulators to look after them, and whether inadequate consumer protection regulation was a contributor to the financial crisis. ${ }^{4}$ While politically engaging, these arguments risk distracting attention from two important principles that should be at the heart of the discussion. First, consumer protection regulation is provided by all financial regulators and is warranted irrespective of the rationality of consumers or the immediacy of financial crises. Second, the need to modernize U.S. financial services regulation is clear and regulatory reorganization is an important part of that agenda.

To begin to refocus the debate it may be useful to recall that an independent consumer protection agency was part of the Blueprint for financial regulatory reform developed and proposed by the Treasury Department under the Bush Administration, and thus is not solely a response to the financial crisis or driven by ideological desires to increase the role of government. ${ }^{5}$ The potential role for a CFPA should be examined based on consideration of the benefits and shortcomings of current consumer protection regulation, and of how a dedicated consumer protection regulator would change things. Specific details of proposed legislation that affect the structure and authority of a CFPA are clearly important. However, these should be evaluated separately and should not be used to determine whether a separate CFPA is a good idea or a bad one. Consideration of the general principles for and against establishment of an independent CFPA may help to illuminate the strengths and weaknesses of specific legislative proposals.

\footnotetext{
${ }^{4}$ See, for example, Senate Committee on Banking, Housing and Urban Affairs (2009); McCoy (2009); Wright and Zywicki (2009).

${ }^{5}$ The "Blueprint" is Department of Treasury Blueprint for a Modernized Financial Regulatory Structure, U.S. Department of Treasury 2008.
} 


\section{The Need for Consumer Protection Regulation}

The primary motivation for consumer protection regulation in financial markets is the fact that consumers have less information than sellers about product attributes, prices and seller quality. Together, these factors determine product quality and so the central information problem facing consumers in financial markets is judging product quality. The costs to consumers of obtaining information on financial product quality are significant. The quality characteristics of financial products are often difficult to ascertain due to the complex set of contingencies determining the benefits and costs of the product over its lifetime; the contingent nature of services, fees and rates of returns; and the fact that these may change over time. Because product differences across sellers are often manifest as differences in these features, quality comparisons across sellers may also be difficult. ${ }^{6}$

Counterbalancing these problems are competitive market forces which should work to protect consumers. Because of the intangible nature of financial products and services, consumer confidence is central to the existence and functioning of markets for these goods. Financial firms thus have strong incentives to maintain consumers' faith in their products and reputations, as do the financial services industries collectively. Such reputation constraints on quality will work only imperfectly, however. The difficulties that consumers face in judging quality mean that consumers’ assessment of a seller’s reputation will adjust only slowly to new information and will be based partly on the reputation of the industry as a whole. This slow adjustment may create situations in which some sellers have an incentive to deliberately misrepresent or provide lower quality in order to earn higher profits in the short run. The longer the length of time it takes until consumers recognize seller quality reductions or misrepresentations, the greater the risk that such actions will yield benefits to

\footnotetext{
${ }^{6}$ See, for example, the discussion of product complexity and resulting difficulties of comparison shopping in the market for hybrid adjustable rate mortgages in McCoy (2009).
} 
sellers. If, additionally, consumers face cognitive or psychological limitations as well as cost barriers to becoming informed, firms may find it profitable to design products that take advantage of these limitations. $^{7}$ In light of these market failures, regulation to ensure product quality and seller honesty may both aid consumers and assist the efficient functioning of financial markets. ${ }^{8}$

Because the rationale for consumer protection regulation rests on information failures, U.S. regulation has evolved to emphasize disclosures. For most financial products, the government requires extensive disclosure of information to consumers prior to purchase and over the life of the product. Part of the recent debate about financial regulatory reform is over whether disclosure regulation provides consumers with sufficient protections. Some consumers may find it difficult to make effective use of disclosures; firms may face competitive pressures to innovate in ways that skirt disclosure requirements; and disclosure requirements may lag behind market innovations. Traditionally, these shortcomings of disclosure regulation have often led to arguments for direct regulation or prohibition of certain actions or products. More recently, concerns about market distortions created by overly restrictive regulations have motivated interest in a middle ground of less restrictive, so-called behaviorally-informed policies that provide consumers with cues or default options to help improve decision making. ${ }^{9}$

\section{The Current Regulatory Architecture}

Financial regulation in the U.S. is organized along institutional lines. Different types of financial institutions have different regulators, and each regulatory body is responsible for

\footnotetext{
${ }^{7}$ See Bar-Gill and Warren (2008) for a comprehensive summary of empirical evidence that consumers are imperfectly informed in credit markets; and Barr, Mullainathan and Shafir (2008b) for discussion of the relationship between consumer psychology and sellers’ incentives.

${ }^{8}$ In principle, this may be accomplished either through industry self-regulatory organizations or through government regulations. Industry self-regulation is widely practiced internationally in the securities industry, for example. Government regulation is a substitute for self-regulation and provides stronger enforcement powers and less susceptibility to capture by industry interests.

${ }^{9}$ See, for example, Camerer et. al, 2003; Thaler and Sunstein, 2008; Barr, Mullainathan and Shafir, $2008 \mathrm{a}$.
} 
overseeing all aspects of the operations of the institutions under its purview. This includes regulation focused on safety and soundness (e.g., monitoring financial condition, risk and risk management; writing and enforcing rules to enhance financial soundness; and dealing with failing institutions) and regulation focused on market conduct (e.g., monitoring selling practices; enforcing compliance with consumer protection regulations; dealing with consumer complaints; and providing consumer education). In principle, both of these regulatory functions protect consumers, but in specific decision contexts their objectives will often conflict. For example, some seller practices that lead to higher profitability may enhance safety and soundness objectives but denigrate consumer protection objectives. ${ }^{10}$ While highly centralized within each sector of the financial services industry, this division of regulatory authority along institutional boundaries is highly decentralized when the industry is viewed in its entirety. Banks, for example, may choose to operate under a state charter or a federal charter. Federally chartered banks are regulated by the Office of the Comptroller of the Currency (OCC) and federally chartered thrifts are regulated by the Office of Thrift Supervision (OTS), both within the Treasury Department. The Federal Reserve Board (Fed) oversees bank holding companies. Federal credit unions are regulated by the National Credit Union Administration. State chartered banks, thrifts and credit unions are regulated by the states, although regulatory responsibilities are shared with federal regulators. Regulatory authority is shared with the Fed in the case of state-chartered banks that are members of the Federal Reserve System, and the Federal Deposit Insurance Corporation (FDIC) shares regulatory authority for all banks. The FDIC also insures banks deposits and resolves insured institutions that have failed.

Insurance companies, in contrast, may only be state-chartered and are regulated by the individual states. The federal role in insurance markets is limited to involvement enabled

\footnotetext{
${ }^{10}$ See McCoy (2009) for discussion of this trade-off in mortgage lending regulation.
} 
by individual laws that address specific types of insurance, insurance arrangements or insuring institutions; or that require states to undertake certain actions in insurance markets in which there is a federal role. Investment institutions are regulated by still other organizations. The Securities and Exchange Commission (SEC) regulates the securities industry, stock and options exchanges, and other electronic securities markets; the Commodity Futures Trading Commission (CFTC) regulates commodity futures and options markets. ${ }^{11}$

To reduce regulatory differences and to coordinate common regulatory initiatives, financial regulators have organized various cooperative bodies. State bank regulators cooperate under the auspices of the Conference of State Banking Supervisors (CSBS) and insurance regulators cooperate through the National Association of Insurance Commissioners (NAIC). Federal bank regulators coordinate through the Federal Financial Institutions Regulatory Council (FFIEC). The costs of coordination within these groups are high as evidenced by disparities in regulations across regulatory jurisdictions and the extremely slow pace of change in cases where common standards are sought. Moreover, coordination of regulation across financial industry sectors is less extensive. ${ }^{12}$

\section{Issues and Problems}

U.S. financial regulation has long been criticized as excessively fragmented, and is increasingly viewed as out of date and out of step with regulatory systems in other countries. Over the past thirty years, many countries have worked to consolidate financial regulatory authority. A growing number of countries, among them the prominent financial centers of the United Kingdom, Germany and Japan, consolidate regulatory authority within a single financial regulator. Many other countries have partially consolidated regulatory authority,

\footnotetext{
${ }^{11}$ The Financial Industry Regulatory Authority (FINRA) is a self-regulatory organization that oversees market conduct of brokerage firms and registered securities dealers.

${ }^{12}$ The Department of Treasury, the Fed, the SEC and the CFTC coordinate through The President's Working Group on Financial Markets, formed in response to the stock market plunge in October 1987 to address issues of systemic risk.
} 
for example by combining oversight of two or more financial sectors (e.g., banking and insurance, or banking and investments) within a single agency. Other countries organize financial regulation by functional areas rather than by institutional boundaries, through the establishment of separate safety and soundness and market conduct regulators, each with authority over all financial institutions. ${ }^{13}$

The impetus for regulatory consolidation generally has been to match the regulatory architecture more closely with financial industry structure. Financial and competitive innovations have led to the growth of financial conglomerates and the blurring of distinctions between different financial products and institutions. The desire to improve systemic risk regulation has been a primary driver of change, but regulatory efficiency and consumer protection regulation have also been at issue. Benefits sought from regulatory consolidation include reducing coordination costs, reducing duplicative regulations, reducing regulatory gaps and avoiding negative effects of regulatory competition.

The fragmented bank regulatory system in the U.S. has proven to be particularly susceptible to regulatory gaps and to harmful regulatory competition. These shortcomings have negative consequences for consumer protection regulation.

Gaps occur when regulatory authority over an institution or a problem is unclear, or when regulatory accountability is shared. When all financial institutions operate within a single industry sector, institutional regulation can minimize gaps. However, institutional regulation of conglomerate firms, or of products that cross institutional boundaries, greatly increases the risk of gaps. In U.S. bank regulation, this problem is exacerbated by the separation of rule-making authority from enforcement authority for the major consumer protection laws. For example, the Fed retains rule-making authority under the Truth in

\footnotetext{
${ }^{13}$ See the World Bank survey of international financial supervisory regimes (Martinez and Rose, 2003) and the discussion in Jackson (2008).
} 
Lending Act (TILA) and the Home Ownership and Equity Protection Act (HOEPA) even though it is not the primary regulator of most financial institutions (by number or assets), and even as the regulated activities have shifted into financial sectors not overseen by the Fed. ${ }^{14}$ This increases the information costs of rule-writing and reduces the effectiveness of regulations as they fail to keep up with market and product changes.

Gaps caused by institutional division of authority reduce the effectiveness of consumer protection regulation. In contrast, regulatory competition may reduce the incentives of regulators to carry out consumer protection regulation. Regulatory competition arises when regulated firms have the ability to choose their regulator. Whether regulatory competition is harmful or beneficial is an empirical question, since the outcome will vary with specific market and regulatory characteristics. Just as in markets, competition between regulators may enhance efficiency if the threat of firms’ choosing an alternative regulator gives regulators incentives to eliminate excessively costly regulations, thus reducing waste and avoiding unproductive regulations. Alternatively, regulatory competition may lead to overly lax regulation if it increases regulator susceptibility to industry rent-seeking. This can lead to a regulatory 'race to the bottom' as regulators vie for a bigger share of the regulatory market by reducing regulations.

Regulatory competition in the U.S. bank regulation system has not eliminated consumer protection regulation: federal laws contain a number of significant consumer protections (Bair, 2003) and U.S. regulation is more stringent than in many other countries (Jackson, 2007). However, lax enforcement of consumer protections has been a problem. For example, Bar-Gill and Warren (2008) note that the Fed acted to update disclosure requirements for credit cards only at the prodding of Congress. McCoy (2009) provides

\footnotetext{
${ }^{14}$ See Jackson (2008) and Bar-Gill and Warren (2008) for discussion of the Fed's rule-writing authority and problems associated with it.
} 
examples of federal bank regulators' failure to police predatory or unfair mortgage lending practices. Wilmarth (2004) reports that, from 1994 to 2004, the OCC did not initiate a single prosecution of a major national bank for violating a consumer protection law. Levitin (2009) notes similarly that the OCC levied only 69 fines during the period 2000-2008, only 6 of which were for consumer protection violations. Mencimer (2007) finds that the OCC’s enforcement pales in comparison to that of state bank regulators, who collectively brought 4,035 consumer enforcement actions against banks in the year 2003 alone.

Despite state bank regulators' stronger record on enforcement actions than federal regulators, in some respects state bank regulators also appear to have a bank-centric focus. Tennyson (2008) analyzes the content of state insurance and banking regulators' websites (in 2007) and finds that state banking department websites provide consumers with poorer access to information and services than their insurance counterparts. Both bank and insurance regulators provide consumers with online information about how to file a complaint against a company. However, while the majority of insurance regulators provide toll-free hotlines (45 states) and/or online complaint filing (39 states), in the case of banking most states require submission of a written complaint by mail or fax. Only 18 state bank regulators allow online filing of complaints and only 20 states offer a toll free phone line for consumers. Insurance regulators also provide consumers better access to complaint statistics about regulated firms. Online complaint statistics are made available on the websites of 26 states insurance regulators but only one state banking regulator's website.

The complex structure of bank regulation presents a further hurdle for consumers to file complaints or to track their bank's complaint record. Because of the multitude of regulators, a consumer wishing to file a complaint against a bank must first determine which regulator has jurisdiction. Most bank regulatory websites list the relevant regulators and often provide links, but consumers must determine which agency is responsible for their 
specific institution before making contact. This creates considerable confusion for consumers. State banking regulators report that nearly 50 percent of complaints received in New York in 2006 (Neiman, 2007) and nearly 60 percent of complaints received in Maine in 2007 should have been made to federal regulators (Maine Division of Banking, 2008). Similarly, FDIC data indicate that nearly one-third of the complaints it received in 2006 were not within its jurisdiction (Tennyson, 2008). After Congressional interest in the problem, federal and state bank regulators began a formal process of complaint sharing in 2007. All of this adds up to suggest that consumer protection does not receive the same priority as safety, soundness and industry promotion among bank regulators. It is interesting that this does not appear to be the case in insurance regulation, even though insurance companies may choose the state in which they are chartered. On the contrary, many observers argue that state insurance regulation is overly focused on consumer protection, creating market inefficiencies as a result. ${ }^{15}$ An important distinction between insurance and bank regulation which may explain this difference is the fact that insurance companies are subject to the laws and regulations of every state in which they operate. That is, the chartering state’s laws do not preempt other states’ laws. In contrast, beginning in the mid1990s, federally regulated banks asserted and won the right to ignore state regulations under the argument that federal law may preempt state law.

Interstate banking was first allowed in 1994 by the Riegle-Neal Act. Concerns about interstate banks being subject to multiple state regulations led to amendments in 1997 that directed the OCC to examine the applicability of state laws to national banks. The extent to which federal regulation may preempt state regulation was interpreted very broadly by the courts, and federal preemption of the states was actively pursued by federal bank regulators

\footnotetext{
${ }^{15}$ For example, see Cummins (2002) and Grace and Klein (2009). Insurance industry pressure for an optional federal charter arises in part from concerns about over-regulation by the states (Harrington, 2006).
} 
(specifically, the OCC and OTS housed within Treasury). In 2004, the OCC asserted full preemption power over state laws (Wilmarth, 2004). There was a concordant shift of bank assets from state to federal banking charters as a result of these changes. Between 1989 and 2003, the share of bank assets under state charters was generally steady around 55 percent, but by 2005 that share had increased to 66 percent (Davis and Rice, 2006). Two of the ten largest commercial banks (JP Morgan Chase and HSBC) converted to a national charter in 2004 alone (Bar-Gill and Warren, 2008).

Strong preemptive powers are what really lead to regulatory arbitrage. Federal preemption eliminates regulatory checks and balances by preventing states from applying more stringent regulations than those applied by a bank’s federal regulator. Similarly, restriction of the FTC's jurisdiction to non-bank financial institutions eliminates regulatory checks and balances. The ability to choose their regulator provides banks with leverage over regulators, because an agency's influence and in some cases its budget is affected by the total assets of the entities regulated. Wilmarth (2004) and others note that assessments from regulated banks comprise virtually the entire OCC budget. This provides an interesting context in which to view OCC preemption of state regulations.

A recent U.S. Supreme Court ruling weakens federal preemption of states' actions to protect consumers of financial services, however. In the case of Cuomo v. The Clearing House Association, the Court affirmed in June of 2009 that states may enforce compliance with their consumer protection laws by national banks. The states' authority to do so had been challenged under the guise of federal preemption, a line of reasoning that was supported by the OCC. The Court's ruling does not invalidate the OCC's preemption of state banking regulations, but gives the states an additional tool to police national banks’ conduct through 
actions brought by state attorney generals. ${ }^{16}$ This establishes state enforcement power as a check on federal inaction. It may also reduce incentives for a 'race to the bottom' among the competing federal bank regulators because regulators do not have the final say on acceptable market conduct. It does not reduce regulatory gaps, however, and creates more potential for regulatory fragmentation due to differing state laws.

\section{A Consumer Financial Protection Agency}

Proposals for a CFPA are based on the idea that what is needed to remedy federal regulatory failures is a new agency with a single focus on consumer protection and broad authority to regulate all sellers of financial services. Such an agency would address the underlying structural issues that reduce attention to consumer protection in the current regulatory system. A CFPA would not find its consumer protection mission hindered by a competing focus on firm solvency due to institutionally based regulation, by regulatory gaps arising from dispersed authority, or by regulatory arbitrage brought on by chartering competition (Levitin, 2009; McCoy, 2009). That does not imply, however, that a CFPA is the only or the best solution. Having laid out the problems with current consumer protection regulation, we should examine the benefits and costs of a range of alternative responses in order to design a better regulatory model.

One advantage of establishing a CFPA is it creates a highly motivated regulator with a well-defined core mission. If granted sufficient authority and funding, such an agency can develop and implement a strong regulatory agenda. However, a strong highly motivated regulator may have a tendency to over-regulate, especially if given a narrowly focused mission. One argument in favor of institutionally-based regulation is that each regulator must balance the desire to protect consumers with the need for an efficient, profitable, and solvent

\footnotetext{
${ }^{16}$ J. Stempel, Banks on Tighter Leash after High Court Ruling, Reuters Jun 29, 2009; B. Wingfield and D. Fisher, Roberts Court Veers from Pro-Business Tack, Forbes.com Jun 29, 2009.
} 
industry; and is in a position to observe the impact of regulations on both sides of the market. Appropriate balance is difficult to obtain and current U.S. bank regulation has placed too little emphasis on consumer protection; but an agency with the sole mission of protecting consumers may push too far in the opposite direction. This concern may be especially salient to some observers because the creation of a CFPA has been marketed as a response to the recent financial crisis. A regulatory agency created as an immediate response to a crisis may be prone to politicized responses that lead to over-regulation. ${ }^{17}$

The opposite concern also arises -- that lacking in authority or starved of funding, a separate consumer protection agency will be unable to fulfill its mission. A stand-alone CFPA may be more easily deprived of adequate authority or funding by opponents of its mission. This could occur in the enabling legislation or in the budgetary process in future years. ${ }^{18}$ Perhaps for this reason, current proposals for a CFPA include the provision that it be financed by fees from regulated firms. Based on the experience of the OTC, some observers fear that this would lead to undue industry influence over the agency and reduce its effectiveness (McCoy, 2009). However, as noted earlier, fee-based funding alone does not lead to regulatory capture. A CFPA's lack of chartering authority and its broad authority over providers of banking products will reduce its susceptibility to regulatory arbitrage. ${ }^{19}$

A separate concern about a CFPA is its lack of regulatory expertise. An alternative that would build on existing regulatory competencies is to provide current regulatory agencies with stronger directives. The main risk of this approach is that internal agency decisions to reduce budget, authority or staffing could undermine the consumer protection

\footnotetext{
${ }^{17}$ Joskow (2009) provides an insightful discussion of industrial regulation and deregulation and raises concerns about the recent financial crisis being used as a rationale for re-regulating the economy.

${ }^{18}$ Examples of narrowly focused agencies that have faced such difficulties include the Occupational Safety and Health Administration (OSHA) and the Consumer Product Safety Commission (CPSC).

${ }^{19}$ See Levitin (2009) and Bar-Gill and Warren (2008). Other observers raise concerns that the proposed CFPA does not consolidate consumer protection regulation far enough - because it does not include institutions regulated by the SEC, CFTC or state insurance regulators (Scott, 2009; Tatom, 2009). This continues the threat of regulatory gaps and regulatory arbitrage.
} 
function. For example, the Fed has strong consumer protection rule-making authority and has recently begun to exercise it by rewriting credit card disclosure rules and banning overdraft fees for ATM and debit card transactions. However, its persistent failure to do so prior to the financial crisis demonstrates the potential for ideology or rent-seeking to affect the allocation of attention.

For this reason, it is important that the consumer protection mission is provided equal authority and an independent funding stream. It would be possible to design these features into existing regulatory agencies by enhancing divisional authority and providing funding through industry fees. This would have the advantage of making use of existing organizational infrastructure. It would also preserve any synergies between market conduct and safety and soundness regulation within each agency (Schooner, 2005). However, assuring the continuing equality and independence of consumer protection regulation would present a larger challenge under this approach.

Providing the Federal Trade Commission (FTC) with additional regulatory authority over financial institutions is another approach that would take advantage of existing regulatory missions and competencies (Schooner, 2005). The FTC is an independent federal agency with a broad consumer protection mission and has experience and expertise in oversight of consumer financial products offered by non-bank institutions. Moreover, the FTC's consumer protection mission includes that of promoting competition in markets. This broadens the FTC's perspective to include the goal of market efficiency and may reduce the likelihood that it would choose overly-intrusive consumer protection regulations (Rosch, 2009). Another check on over-regulation by the FTC may be its responsibility for consumer protection in all economic sectors, not just financial institutions. This requires resources to be allocated to various industries and problems based on the relative need for regulatory action. 
The FTC regulates mainly through ex post intervention in the case of deceptive or misleading practices by a firm, and through provision of rulings to industries regarding disclosures that would satisfy regulatory standards. Financial regulators generally use a broader array of regulatory tools than the FTC, and so the question of whether disclosure provides sufficient consumer protections in financial services becomes vital when considering the FTC as a regulator. ${ }^{20}$ Providing the FTC with authority to approve or design financial products or to conduct routine compliance examinations would broaden the agency’s mission beyond its expertise.

Coordination difficulties between the FTC and bank regulators may also arise if the FTC is given expanded authority over financial institutions. Although the FTC has a history of cooperation with bank regulators and especially with the Fed (Rosch, 2009), adding another agency to the plethora of existing bank regulators will undoubtedly increase rather than decrease coordination costs. Not only will coordination costs be larger by virtue of communicating across agency boundaries, but also by virtue of the different cultures likely to be present in regulators with distinctly different missions. Of course, this will also be the case if a CFPA is created. Coordination costs may be even greater with a CFPA because it would have to coordinate with the FTC as well as with bank regulators. ${ }^{21}$ That said, coordination costs between a CFPA and bank regulators would likely be lower than those for the FTC due to greater potential for coordination through the Department of Treasury or the (proposed) Financial Services Oversight Council (membership to include all of the major bank regulators, the SEC, the CFTC and others). ${ }^{22}$

\footnotetext{
${ }^{20}$ See Bair (2003) and Schooner (2005) for a discussion of regulatory tools used by bank regulators.

${ }^{21}$ Current legislative proposals strip the FTC of much regulatory authority in financial services industries, but provide it with some "backstop authority" to bring enforcement actions; these seem likely to create interagency tensions and turf battles (see Kovacic, 2009).

${ }^{22}$ This is a provision in H.R. 3996, The Financial Stability Improvement Act of 2009 and is included in the comprehensive financial reform bill H.R. 4173 recently passed by the full House.
} 


\section{Conclusions}

The current system of U.S. bank regulation is fragmented and inefficient and does not adequately fulfill its consumer protection mission. To assure consistent and continuing oversight over the long run, increased authority for consumer protection regulation should be established and this authority should be supported by a dedicated funding stream insulated from shifts in the political environment.

A new Consumer Financial Protection Agency funded by fees from industry is one way to achieve this. An important strength of the CFPA proposal is the consolidation of consumer protection regulation in a single financial regulatory agency. All banking institutions would be subject to a common set of enforcement standards and would be unable to avoid compliance by choosing a different regulator or using the threat of choice to weaken regulatory enforcement. A CFPA would also guarantee the long term independence and vitality of the consumer protection mission in the bank regulatory system.

But despite consolidating consumer protection regulation, in other ways the CFPA would exacerbate the current problems of fragmentation and inefficiency in the regulatory system. The need to coordinate with each of the other bank regulators would multiplicatively increase the transactions costs and coordination costs of policy. A related concern is the possibility of over-regulation due to the agency's single focus on consumer protection. This would reduce market efficiency and would bring the CFPA into direct conflict with other bank regulators. A coordinating body such as the Financial Services Oversight Council proposed in current legislation could help to mitigate these problems; but creating a consolidated CFPA and leaving the remaining bank regulatory structure intact will undoubtedly lead to high coordination costs and multiple inter-agency conflicts.

With this trade-off in mind, creation of a CFPA makes the most sense if undertaken as part of a phased move toward greater consolidation of financial regulation. This could be 
achieved by creating a single consolidated financial services regulator or a so-called twinpeaks system with a single safety and soundness regulator and a single consumer protection regulator. Although conflicts between different regulatory objectives would still occur, the elimination of multiple safety and soundness regulators would lessen both the costs of coordination and the threat of regulatory arbitrage that affects those regulators. Consultation between two regulators of equal stature (whether within or between agencies) would level the field for negotiations and simplify information sharing. This would improve the efficiency of all aspects of financial regulation.

Current House proposals take only a small step in this direction by merging the OTS into the OCC but leaving other financial regulators intact (see H.R. 3996 and H.R. 4173). A Senate bill, Restoring American Financial Stability Act of 2009, introduced by Senate Banking Committee Chairman Christopher Dodd (D-CT), contains proposals for greater consolidation but has not yet been approved by Committee and may change substantially in the markup process.

Absent regulatory consolidation, it may be preferable to leave existing institutional authorities intact and enhance the resolve of financial regulators through new directives and dedicated funding for consumer protection. McCoy (2009) notes that the OCC and OTS mission statements emphasize bank safety and soundness; McCoy further notes that the Fed mission statement emphasizes monetary policy and bank regulation, with not even a mention of consumer protection. Bar-Gill and Warren (2008) observe that Congress has tended to provide consumer protections in financial services through narrowly focused legislation that is enforced by the Fed and the bank regulators. Legislation could instead be aimed toward establishing a strong, independently-funded consumer protection agenda for these regulatory agencies, while preserving the Fed's current rule-writing authority to ensure the same regulations apply to all firms. This would move the system toward a more equal balance of 
consumer protection and safety and soundness regulation without the disruption and costs associated with adding a CFPA to the mix. 


\section{References}

Barr, M.S., S. Mullainathan and E. Shafir. 2008a. "Behaviorally Informed Financial Services Regulation.” New American Foundation Working Paper, October.

Barr, M.S., S. Mullainathan and E. Shafir. 2008b. "Behaviorally Informed Home Mortgage Credit Regulation.” Ch. 6 in Borrowing to Live: Consumer and Mortgage Credit Revisited. P. Retsinas and E.S. Belsky, eds., Washington: Brookings Institution Press.

Bair, S. 2003. Consumer Ramifications of an Optional Federal Charter for Life Insurance. Isenberg School of Management, University of Massachusetts. http://www.isenberg.umass.edu/finopmgt/uploads/textWidget/2494.0 0004/documents/bair-cons-ramifications.pdf.

Bar-Gill, O. and E. Warren. 2008. “Making Credit Safer.” University of Pennsylvania Law Review 93(1).

Camerer, C. et al. 2003. "Regulation for Conservatives: Behavioral Economics and the Case for Asymmetric Paternalism.” University of Pennsylvania Law Review 151.

Cummins, J.D., ed. 2002. Deregulating Property-Liability Insurance: Restoring Competition and Increasing Market Efficiency. Washington: AEI-Brookings Joint Center for Regulatory Studies.

Davis, R. and T. Rice. 2006. "Federal Preemption of State Bank Regulation: A Conference Panel Summary,” Chicago Fed Letter, September 1.

Grace, M.F. and R.W. Klein, eds. 2009.The Future of Insurance Regulation in the United States. Washington: Brookings Institution Press.

Harrington, S.E. 2006. "Federal Chartering of Insurance Companies: Options and Alternatives for Transforming Insurance Regulation.” Networks Financial Institute Policy Brief 2006-PB- 
02. http://www.networksfinancialinstitute.org/Lists/Publication\%20Library/Attachm ents/36/2006-pb-02_Harrington.pdf.

Jackson, H.E. 2007. “Variation in the Intensity of Financial Regulation: Preliminary Evidence and Potential Implications.” Yale Journal on Regulation 24(2).

Jackson, H.E. 2008. “A Pragmatic Approach to the Phased Consolidation of Financial Regulation in the United States.” Harvard Public Law Working Paper \#09-19.

Joskow, P.L. 2009. Deregulation: Where Do We Go From Here? Washington: AEI Center for Regulatory and Market Studies.

Kovacic, W. 2009. “The Consumer Financial Protection Agency and the Hazards of Regulatory Restructuring.” Lombard Street 1(12). September 14. http://www.finreg21.com/lombard-street/the-consumer-financial-protectionagency-and-hazards-regulatory-restructuring.

Levitin, A.J. 2009. “Hydraulic Regulation: Regulating Credit Markets Upstream.” Yale Journal on Regulation 26.

Levitin, A.J. 2009. “The Consumer Financial Protection Agency.” Pew Financial Reform Project, Briefing Paper \#2 (2009).

Martinez, J.L, and T.A. Rose. 2003. International Survey of Integrated Financial Sector Supervision. World Bank Policy Research Working Paper 3096.

McCoy, P.A. 2009. Testimony before the U.S. Senate Committee on Banking, Housing, and Urban Affairs. March 3.

National Association of Insurance Commissioners 2006. Insurance Department Resources Report. Kansas City: NAIC.

Neiman, R.H. 2007. Testimony before the Financial Services Committee Subcommittee on Financial Institutions and Consumer Credit. December 12. 
Rosch, J.T. 2009. Testimony before the U.S. House of Representatives Committee on Financial Services. July 21.

Schooner, H.M. 2005. “Consuming Debt: Structuring the Federal Response to Abuses in Consumer Credit.” Loyola Consumer Law Review 18(1).

Scott, H. 2009. “CFPA Legislation Goes Too Far on Some Issues, Not Far Enough on Others.” The Harvard Law School Forum on Corporate Governance and Financial Regulation. October 27. http://blogs.law.harvard.edu/corpgov/

Senate Committee on Banking, Housing and Urban Affairs. 2009. “Summary: Restoring American Financial Stability,” Discussion Draft.

Tatom, J.A. 2009. “Responding to the 2007- 09 Financial Crisis: A New Consumer Financial Protection Agency?” MPRA Paper No. 16174. July. http://mpra.ub.unimuenchen.de/16174/1/MPRA paper 16174.pdf.

Tennyson, S. 2008. “State Regulation and Consumer Protection in the Insurance Industry.” Networks Financial Institute Policy Brief 2008-PB-

03. http://www.networksfinancialinstitute.org/Lists/Publication\%20Library/Attachm ents/108/2008-PB-03_Tennyson.pdf.

Thaler, R. and C.R. Sunstein. 2008. Nudge: Improving Decisions about Health, Wealth and Happiness. London: Penguin Books.

U.S. Department of the Treasury. 2008. Blueprint for a Modernized Financial Regulatory Structure. March. http://www.treas.gov/press/releases/reports/Blueprint.pdf.

U.S. Department of the Treasury. 2009. Financial Regulatory Reform: A New Foundation: Rebuilding Financial Supervision and Regulation. http://www.financialstability.gov/docs/regs/FinalReport_web.pdf. 
Wright, J.D. and T.J. Zywicki. 2009. "'Three Problematic Truths about the Consumer Financial Protection Agency Act of 2009.” Lombard Street 1(12). September 14. http://www.finreg21.com/lombard-street/three-problematic-truths-aboutconsumer-financial-protection-agency-act-2009.

Wilmarth, A.E., Jr. 2004. “The OCC’s Preemption Rules Exceed the Agency’s Authority and Present a Serious Threat to the Dual Banking System and Consumer Protection.” Annual Review of Banking and Financial Law 23. 